\title{
Auto-fotografi som metode \\ - når medarbejdertrivsel er et sociomaterielt fænomen
}

\section{Mette Mogensen}

Artiklen sætter fokus på auto-fotografi som metode i arbejdsmiljøforskningen. Den organisationsæstetiske tilgang, som metoden ofte forbindes med, udfordres med afsæt i en performativ og aktørnetværks-teoretisk position. Gennem en analyse af et enkelt auto-fotografi vises hvordan en artikulation af fotografiets objekter og de sociale og materielle forbindelser til organisationen kan forskyde fokus fra et psyko-socialt til et socio-materielt perspektiv på medarbejdertrivsel: Populært sagt findes trivsel også i et støtteben. Artiklen konkluderer at fotometodens potentiale ikke findes i dens æstetiske kvaliteter, men i forskerens evne til at artikulere forskningsfeltet så nye handlemuligheder bliver synlige.

\section{Fotografi som en 'rigere' repræsentation af feltet?}

$\mathrm{F}$ otografi som metode er fortsat en niche inden for arbejdslivs- og organisationsstudier. Der er dog en voksende interesse for tilgangen, ikke mindst inden for etnografien og den organisations-æstetiske forskning (Pink 2001; Grimshaw \& Ravetz 2005; Strati 2008; Warren 2002). I denne sammenhæng er det primært sidstnævnte som er i fokus.

I det organisationsæstetiske forskningsfelt ses fotografi som en måde at opnå en bedre adgang til det empiriske felt, forstået som en mere mange-facetteret repræsentation (Schwartz 1989; Warren 2002; 2008; Strati 2008). Fotografiet menes at kunne repræsentere en viden som ellers normalt udelukkes fra studier i og af organisationer. En viden som Gagliardi forbinder med: "the unconscious, or tacit and ineffable" (Gagli- ardi 2006). Det er en form for viden som forbindes med kroppen og dens sanser, og som kun vanskeligt lader sig repræsentere via ord. Som sådan ses fotografiet som et alternativt 'vokabularium' der bryder med sprogets dominans i akademia (Strati 2000; 2008). Det hænger sammen med at fotografiet og billedmediet menes at kunne vække ikke blot synssansen, men samtlige sanser (Pink 2001; 2009; Pink et al. 2004; Macdougall 2006). Af samme grund argumenterer fortalere for at metoden forlener forskeren med en større grad af sensitivitet overfor felt og informanter, eftersom det er hele forskerens krop, 'the whole human sensorium' (Pink 2009), der involveres i det at se. Den sanselige etnografs opgave er ifølge Pink:

" (...) to seek to know places in other people's worlds that are similar to the places and ways of knowing of those others. In attempting to achieve this, she or he would aim to 
come closer to understanding how those other people experience, remember and imagine" (Pink 2009, 23).

Den videnskabsteoretiske klangbund for organisationsæstetikernes argumentation er typisk fænomenologisk inspireret; orienteret mod fotografens såvel som beskuerens kropslige oplevelse. I tråd hermed præsenterer Warren fotografiet som en del af en 'sensual methodology' (Warren 2002) defineret ved sin umiddelbarhed, sin 'immediacy' (Warren 2005, 864). Hun er her på linje med den franske semiotiker og filosof, Roland Barthes, som i sin bog Det lyse kammer (Barthes 1983) præcist lægger vægt på fotografiets oplevelsesmæssige kvalitet. Barthes taler om fotografiet som noget der "angriber" beskueren og på den baggrund skaber en langt mere umiddelbar sansning og viden - i kontrast til det rationelle og kultiverede "studium" (Barthes 1983, 31). I et organisationsæstetisk perspektiv opfattes synet og billedmediet altså som et redskab til en bedre adgang til feltet, forstået som en sensorisk rigere forståelse for informanternes særlige livsverden. Til trods for at organistionsæstetikerne ser sig selv som værende i direkte opposition til et objektivt videnskabsideal og ej heller hævder at producere andet end en partiel viden (Strati 2000), opstår en paradoksal tendens til at gen-fremmane repræsentations-spøgelset. Symptomatisk bruger Warren følgende citat fra Gagliardi som argument for at arbejde med fotometodens sensuelle metodologi: "The aesthetic experience should be transmitted in ways consonant with its nature" (Warren 2008, 576). Ambitionen om at indfange flere aspekter ved det organisatoriske liv ved hjælp af visuelle metoder baserer sig således på en idé om at kunne repræsentere det Gagliardi betegner som "basic" og "profound" elementer af organisationers liv (Gagliardi 2006, 702). Som var der en mere $\mathrm{dyb}$, oprindelig form for liv at afdække.
Baseret på egne erfaringer med specifikt auto-fotografi som metode (se nedenfor) anerkender jeg fotometodens potentiale, men jeg baserer ikke argumenterne i organisationsæstetikernes idé om at kunne afsløre hidtil uerkendte facetter af virkeligheden eller at kunne etablere en større grad af nærhed og autencitet i relation til informanternes livsverden. Inspireret af aktør-netværksteori (ANT) og en performativ forskerposition lægger jeg vægt på forskerens evne til, via fotometoden, at give feltet mulighed for at blive til noget andet/noget nyt (Latour 2004; Bramming et al. 2009; 2012). Det udelukker ikke fotografens perspektiver, men involverer også andre mulige aktører. Fotometoden indebærer for eksempel et særligt blik for objekterne; for mondæne objekter som støtteben og cykler der i den præsenterede analyse viser sig at have betydning for arbejdet og dermed medarbejdernes trivsel. Artiklen præsenterer en alternativ metodologisk indfaldsvinkel til auto-fotografiet hvor forskerens opgave er at artikulere billedet ved at tilføje flere ressourcer end fotografens (og forskerens) oplevelseskategorier og derved synliggøre de mange forbindelser mellem fotografiet og et større organisatorisk netværk. Det er samtidigt ad den vej fotometoden kan skabe ny viden om arbejdsmiljøet.

\section{Auto-fotografi}

Ser man på fotometoden med prefixet auto, som er fokus for denne metodeartikel, så er den karakteriseret ved at man som forsker lader informanterne selv tage billeder. Autofotografi er i særlig grad blevet taget i anvendelse inden for forskning som interesserer sig for personer der af den ene eller anden grund har vanskeligt ved at udtrykke sig i ord. Det har for eksempel drejet sig om børn (Rasmussen 1999; Staunæs 2000) og hjemløse (Johnsen et al. 2008). Derudover 
har den allerede citerede engelske organisationsforsker, Samantha Warren, de seneste år brugt og skrevet en del om auto-fotografi som metode i en arbejdslivssammenhæng, med særlig vægt på metodens evne til at afdække de følelsesmæssige aspekter af arbejdet (Warren 2002; 2005; 2008; Shortt \& Warren 2012). Styrken ved auto-fotografiet er at de billeder der bliver taget ikke er begrænset af forskerens udsyn, men derimod tilbyder informanter det Warren kalder 'a photo-voice' (Warren 2005). En pointe om involvering af informanterne som også er blevet fremhævet af danske forskere. Her præsenteres autofotografiet (snaplog metoden) netop som særligt velegnet fordi "feltet får en chance for at gøre andet og mere end lydigt at bedrive 'spontan sociologi' efter forskerens pibe" (Bramming et al. 2009, 31). Prefixet auto kan således siges at indskærpe fotometodens ambition om en rigere og bedre repræsentation af feltet ved at den ikke blot giver adgang til flere nuancer i feltet (sammenlignet med konventionelle metoder), men samtidigt giver informanterne mulighed for i højere grad selv at definere det som skal udforskes.

\section{Farvel til mysticisme}

Argumenterne for brug af fotografi som metode, uanset om det er med auto-prefixet foran eller ej, har dog en tendens til at fremstå mystiske. I hvert fald er det uklart hvad forskeren reelt skal gøre når vedkommende konfronteres med billedmaterialet. Når organisationsæstetikerne taler om at fotografiet 'angriber' beskueren, undslipper rationaliteten og kalder på vores umiddelbare indlevelse og følelsesmæssige engagement, så kan det virke forfriskende og måske også forførende. Når det oven i købet loves at fotografiet kan repræsentere 'mere' af verdens mangfoldighed sammenlignet med traditionelle metoder, så kan det være vanskeligt at afvise. Det betyder imidler- tid ikke at det reelt bliver mere klart hvad det er metoden kan. Når Strati eksempelvis opfordrer forskeren til at deltage i "(..) an evocative knowledge production process" og at forskere skal "project themselves into the situation" (Strati 2009, 235, 239), hvad indebærer det så mere præcist? Som også Warren har påpeget, så er der al mulig grund til at præcisere fotometodens metodologiske afsæt: "the how of aesthetics research" (Warren 2008, 559), eftersom netop denne dimension ofte negligeres til fordel for en fejring af langt mere abstrakte filosofisk-æstetiske koncepter og humanistiske dyder. Det er langt fra sikkert at fotografierne 'taler for sig selv' endsige 'angriber' beskueren. Det kan, som Chalfen har påpeget, lige såvel tænkes at fotografiet efterlader en form for 'paralyse': en tilstand hvor billedets åbenbare repræsentation af virkeligheden efterlader forskeren $\mathrm{i}$ en tilstand af lammelse og rådvildhed (Chalfen 2001). Når postarbejderne tager billeder af en postkasse, en hund, en sol og en udsigt er det således oplagt at disse 'objekter' har en betydning for en god arbejdsdag, men straks mindre klart hvordan (Mogensen 2012).

I det følgende vil jeg præsentere et alternativ til den organisationsæstetiske forståelse af fotometoden med afsæt i ANT. Dernæst vil jeg præsentere mine konkrete erfaringer med metoden i Post Danmark ${ }^{1}$ og ved hjælp af en specifik analyse af et auto-fotografi tydeliggøre hvordan fotometodens potentiale i høj grad afhænger af det efterfølgende analysearbejde; det at se og (gen)beskrive det enkelte motiv som en del af et større netværk.

\section{Subjektivitet, krop og videns- produktion - historien om 'Næsen'}

"No subjectivity, no introspection, no native feeling can be any match for the fabulous proliferation of affects and effects that a 
body learns when being processed by a hospital. Far from being less you become more" (Latour 2004, 227).

Citatet ovenfor er fra Latours artikel: "How to talk about the body. The normative dimension of science studies" (2004) og fungerer som en provokatorisk kritik af et fænomenologisk perspektiv. Teksten diskuterer hvad det vil sige at producere viden og i den forbindelse hvordan relationen mellem det erkendende subjekt og det erkendte objekt kan forstås. Som citatet gør klart, så placerer Latour sig i den forbindelse i opposition til fænomenologien og det han opfatter som dens grundessens: At det erkendende subjekts evne til indlevelse og nærhed er en forudsætning for god/interessant vidensproduktion. At producere viden om feltet handler, ifølge Latour, heroverfor ikke om autentisk væren med og i feltet, men snarere om at iværksætte diverse kunstige mediationer således feltet kan fremstå så nuanceret som muligt. Som et alternativ til den organisationsæstetiske krop - en naturlig og prædefineret sensorisk kapabilitet - bliver den erkendende krop, såvel som feltet selv, til i relation til diverse standarder og instrumenter. I teksten refererer Latour til et specifikt eksempel som samtidigt er interessant fordi det parafraserer og udfordrer en af de mest fremtrædende organisationsæstetikeres udlægning af samme fænomen (se Strati 2008). Det fænomen Strati og Latour begge tager afsæt i er uddannelsen af såkaldte 'næser', det vil sige personer inden for parfumeindustrien som er ansat til at udvikle og vurdere dufte. Mens Strati bruger uddannelsen til 'næse' som en illustration af hvad det vil sige at udvikle en særlig æstetisk kompetence, og peger på de sensoriske egenskaber hos personen som udslagsgivende for evnen til at skelne den ene duft fra den anden, så er Latours pointe en ganske anden. Ifølge Latour kan man ikke forstå 'næsens' særlige kompetencer uafhængigt af det 'nose-kit' som indgår i uddannelsen. 'The nose-kit' er en lille trækasse som indeholder små flasker med forskellige dufttyper. Dufttyper som helt almindelige mennesker, inklusiv den uerfarne 'næse' selv, ikke er i stand til at skelne fra hinanden. Det er noget 'næsen' først skal lære. Ikke som følge af sine særlige sensoriske egenskaber, men som følge af de distinktioner som den lille trææske med de forskellige flakoner formår at etablere. Pointen er at den erkendende krops sensoriske kapabilitet, i dette tilfælde repræsenteret ved 'næsen', ikke er givet qua menneskets natur og dets medfødte sensoriske egenskaber, men derimod skabes i mødet med 'the nose kit'. 'Næsen' lærer, ifølge Latour, at blive berørt gennem en række kunstige mediationer (Ibid., 209). Heraf følger samtidigt en lige så væsentlig pointe nemlig at duftene ikke blot findes derude i verden og blot venter på at blive opfanget af 'næsen', men reelt først bliver til som dufte i kraft af 'the nose-kit': "(...) through the mediation of an artificially created set-up" (Op.cit.). At erkende verden handler hverken om at fjerne alle former for mediationer for at opnå den mest direkte og 'rene' adgang til verden (som er tilfældet inden for en objektivistisk videnskabstradition); endsige at opøve sin evne til at sanse verden mere udtømmende og således få adgang til en hidtil utilgængelig dimension af verden som synes at være argumentet når fotometoden tages op af organisationsæstetikerne. Ifølge Latour er den eneste mulige og mest interessante viden om verden dén som skabes gennem kunstig mediation, eller 'articulation'. Som Latour siger:

"The main advantage of the word articulation is not its somewhat ambiguous connection with language and sophistication, but its ability to take on board the artificial and material (...)" (Ibid., 210). 
I modsætning til idealet om nøjagtig repræsentation har artikulation i princippet ingen begrænsning. Som Latour fortsætter:

"(...) Articulations, on the other hand, may easily proliferate without stopping registering differences. On the contrary, the more contrast you add, the more differences and mediations you become sensible to" (Op.cit.).

Med afsæt heri så kan auto-fotografiet ikke forstås som en metode til at etablere en mere 'sand' viden, forstået som en mere autentisk adgang til feltet og det fænomen som undersøges. Fotografierne er i princippet blot én mediation blandt flere mulige som gør forskeren i stand til at skabe distinktioner og dermed artikulere feltet på potentielt nye måder (se også Mogensen 2011). Når det handler om postarbejderens trivsel, bliver auto-fotografierne således en del af mit 'nose-kit', eller det jeg andetsteds har betegnet som "a seeing device" (se Mogensen 2012, 86). Som pendant til historien om 'næsen' så gør auto-fotografierne det muligt for mig at se feltet, ikke blot som det opleves af mine informanter, men at se feltet som det bliver til i mine forskellige forsøg på at gøre det synligt. Auto-fotografierne er selvsagt et væsentligt element i dette 'seeing device', men virker ikke fordi det inviterer mine sanser til en mere autentisk indlevelse i feltet, eller fordi det forlener informanterne med en sanselig repræsentationsmodus.

\section{Fotometoden i et performativt perspektiv}

Autofotografi er tidligere blevet præsenteret og diskuteret her i tidsskriftet under betegnelsen 'SnapLog' (Bramming et al. 2009), og i tråd med ovenstående (videnskabs) teoretiske positionering så deler denne artikel den position som Bramming et al. præsenterer: at fotometoden kan ses som en performativ forskningsteknologi (se også Bramming et al. 2012). Den visuelle metode repræsenterer ikke blot feltet i sin mangfoldige rigdom; som det reelt opleves af informanterne. Den er derimod med til at skabe feltet på en særlig måde. Som Bramming et al. fremhæver, så kan snaplog-metoden være med til:

"at skabe alternative og måske nye måder, hvorpå både felt og forsker kan forstå den problemstilling, der undersøges" (Bramming et al. 2009, 28).

Metodens kvalitet ligger med andre ord i dens evne til at give feltet mulighed for at blive til noget andet/mere og dermed yde modstand mod tidligere vedtagne kategorier. Det er netop dét Latour mener når han i citatet ovenfor taler om at 'articulation' og 'meditation' tilføjer distinktioner til feltet. Argumentet for at det er muligt med auto-fotografiet at producere denne effekt, er ifølge Bramming et al. særligt auto- præfixet: at det er informanterne selv der tager billeder og således definerer hvad forskeren får øje på i feltet (Ibid., 31). Som også Bramming et al. er inde på, inspireret af en postfeministisk forskningstradition, er forskerens positionering i felten imidlertid lige så afgørende. Forskeren udtaler sig altid et sted fra, og er med dette særlige blik (og sine metoder) aktivt med til at definere hvad feltet kan udtrykke (Haraway 1991). Forskerens fornemmeste opgave er at tage sin position på sig og derudfra, i samarbejde med informanterne, at finde nye måder at artikulere feltet på (se også Krøjer 2010).

I relation til den kommende analyse og denne forsker handler det om at bidrage til en ny forståelse af postarbejderes trivsel og mere generelt af det psyko-sociale arbejdsmiljø. En forståelse som tager et andet afsæt end det enkelte individ; både når det handler om at identificere arbejdsmiljøproblemer 
og at gøre noget ved dem. Som Michael Pedersen har demonstreret i sine analyser af stress-selvhjælpsbøger, så indgår individuelle coping-strategier som en væsentlig ingrediens i det maskineri af produktivitets- og selvforbedring som i første omgang er med til at få medarbejderne til at gå ned med stress (Pedersen 2008). Set i lyset af den enorme eksponering individet er udsat for på arbejdspladsen i ledelsessammenhæng, men i princippet også i meget arbejdsmiljøarbejde, så ligger der i den analytiske forskydning væk fra individet og dets psykologi en potentiel mulighed for at tage noget af presset væk fra selvsamme individ. I forlængelse heraf arbejder denne artikel med en forståelse af trivsel som socialt forankret. Som Bramming et al påpeger: "(..) stress opleves individuelt, men opstår i en social sammenhæng" (2009, 26; se også Sørensen et al. 2007). Med inspirationen fra ANT tilføjer artiklen desuden en opmærksomhed på det materielles betydning for trivsel.

En sådan socio-materiel forskerposition er imidlertid ikke blot en (videnskabs)teoretisk markering. Den har naturligvis metodisk-analytiske konsekvenser. Når autofotografierne fungerer som forskerens 'nose kit'/'seeing device' i relation til feltet, er det derfor væsentligt at understrege at auto-fotografierne ikke står alene. Mit 'seeing device' indebærer således flere mediationer i form af empiriske ressourcer: observationer, interviews, dokumenter og ikke mindst en særlig teoretisk begrundet opmærksomhed på 'the extra-somatic', alias de non-humane aktører. Inspireret af ANTs deskriptive ambition om at 'follow the actors' (Latour 2005, 12) leverer analysen detaljerede beskrivelser af de forbindelser som tilsammen giver fotografiet agens, forstået som udsagnskraft i relation til spøgsmålet om medarbejdertrivsel. Min strategi for at producere et alternativ til gængse og ofte individualiserede forståelser af medarbejdertrivsel er således at forfølge de mange forbindelser fra det enkelte fotografi og ud i det større netværk af organisationen Post Danmark. Analysen introducerer derfor aktører og begivenheder som betjener sig af andre logikker end de som er repræsenteret ved fotografen, men som ikke desto mindre viser sig at være konstituerende for fotografiet, og ikke mindst afgørende for at synliggøre medarbejdertrivslens organisatoriske og materielle forankring. Hvad det mere præcist indebærer, vil være fokus i det følgende.

\section{Hvordan kan man 'synliggøre' et auto-fotografi?}

Ser man på den allerede eksisterende litteratur og forskning, så er det mest typiske at billederne gøres tilgængelige ved hjælp af ord. Det vil sige ved hjælp af efterfølgende interviews. Under termer som photo-driving, photo-elicitation og photointerviewing finder man en lang række artikler som på forskellig vis argumenterer for nødvendigheden af at (re)introducere ordene (Harper 2002; Hurdley 2007; Schwartz 1989). Ifølge Schwartz handler det om at interviewene er med til at levere en nødvendig kontekstualisering af billedet:

"(.) the use of photographic methods must be grounded in the interactive context in which photographs acpuire meaning" (Schwartz 1989, 120).

Idet jeg har kombineret fotometoden med en tekstlog, ligger der i loggen allerede en begyndende kontekstualisering. Hver fotograf er blevet bedt om at skrive hvad billedet forestiller, og hvordan det hænger sammen med temaet: 'en god arbejdsdag'. Til billedet af den glade hund stod der således: "Det er en god dag når der er pakker til Mingus og han venter på sin hundekiks"; til udsigten var der tilføjet: "Bedre udsigt på postruten 
findes ikke", mens der til billedet af cyklen med støtteben kort og godt blev konstateret: "En god cykel med støtteben". På grund af teksternes kortfattede karakter var det imidlertid ikke nok til at skabe en forbindelse mellem billedet og en god arbejdsdag. Spørgsmålet var stadig hvad denne kobling bestod af i netop denne organisatoriske sammenhæng? Netværket måtte udvides, flere mediationer måtte i spil.

Ifølge Warren er det væsentligt at inddrage fotografen selv som en central aktør i analyse-processen. Som Warren argumenterer, så er fotografiets specifikke mening nemlig subjektivt defineret

"(...) the specific meaning of the event and the reason for its 'capture' is known only to the photographer. If we accept this inherent subjectivity of photographs made by research participants, as I argue here, then we must also let them explain their photographs to us, drawing out their specific meanings for them" (Warren 2005, 866).

Mit argument er at man med en sådan individualiseret tilgang til billedet og dets motiv risikerer at overse den sociale og kollektive sammenhæng billedet er opstået i, og desuden mister blikket for de specifikke objekter på billedet. De metodiske implikationer jeg valgte at drage heraf, vil blive beskrevet nedenfor.

\section{Fotografiets kollektive betydning og organisatoriske forbindelser}

I modsætning til den måde fotografi og interviews typisk kombineres i litteraturen, har jeg lagt vægt på en kontekstualisering af auto-fotografierne som rækker udover den enkelte informants meningsskabelse. Til det formål gennemførte jeg gruppeinterviews med 4-5 postarbejdere fra hver af de to teams der deltog. De medvirkende i gruppeinterviewet var ikke nødvendigvis de samme som havde taget billederne. Idéen med dette design var netop at bryde med fotografens monopol på fotografiet, og i stedet lægge vægt på billedets kollektive/organisatoriske betydning: de forbindelser postarbejderne i fællesskab, i kraft af deres fælles praksis, var i stand til at etablere. Som optakt til gruppeinterviewet havde jeg på forhånd kategoriseret fotografierne i overordnede temaer: 'Naturen/udenfor', 'Kollegaer og godt samarbejde', 'Gode arbejdsredskaber/fysisk arbejdsmiljø' samt 'Kunder' for på den måde at danne mig et første overblik og samtidigt skabe en struktur for interviewet. I langt de fleste tilfælde blev denne tematisering bekræftet af informanterne. Jeg startede dog altid dialogen om hvert billede med en åben invitation til én af informanterne om at beskrive billedet hvorefter gruppen i fællesskab bidrog med at uddybe hvordan billedet hang sammen med en god arbejdsdag. Først når gruppen ikke lod til at have mere at føje til billedet, læste jeg den tekst op som fotografen havde knyttet til billedet. Som oftest bekræftede den det der allerede var blevet sagt. Men det kunne også give anledning til endnu en 'runde'. Eksempelvis dukkede et helt nyt tema op da et landligt billede af en snoet grusvej, en grøn busk i vejsiden og en blå himmel som baggrund, viste sig ikke at handle om naturen. Som teksten til billedet slår fast: "Det gør mig bare så glad når jeg ser den busk jeg kan tisse bag". Teksten gav derefter anledning til en diskussion om en årelang kontrovers med Post Danmark: at man som medarbejder ikke har adgang til toiletter, men er afhængig af offentlige toiletter eller kundernes private badeværelser. Sidstnævnte blev af postarbejderne opfattet som grænseoverskridende og noget de kun nødigt indlod sig på. Vådt regntøj og beskidt fodtøj er ikke en optimal indfaldsvinkel til at blive inviteret indenfor, som de påpegede. Flere fortællinger dukkede op. Fortællinger 
om den udsathed som arbejdet ude på ruten repræsenterer: hårdt vejr, de beskidte hænder fra tryksværten, spisepausen som ofte foregår på farten eller helt springes over. Den kollektive indfaldsvinkel til fotografierne gav med andre ord anledning til at få fortalt historier og skabt forbindelser, udover fotografens egne, og understregede dermed medarbejdertrivsel som et kollektivt og ikke mindst organisatorisk fænomen.

\section{Objekterne i fokus}

Et billede er altid et billede af noget. Det kan synes som en banal konstatering, men det er ofte sådan at man som forsker nemt mister netop objekterne af syne. Når man eksempelvis interviewer, så er det i højere grad ordene, tankerne og refleksionerne om objektet, fremfor objektet selv, der kommer i fokus. Schwartz taler decideret om at man må "look through the photograph" for at kunne afdække dets betydning (Schwartz 1989, 122). Når organisationsæstetikerne herudover lægger vægt på "the invisible" og "the intangible" som en væsentlig del af fotografiets berettigelse, giver det også en tendens til at fokus flyttes væk fra objekterne. I stedet overlades scenen til "the atmosphere of the organization" (Strati 2008, 239). Set i lyset af organisationsæstetikernes ambition om sensorisk sensibilitet er dette resultat paradoksalt. Som Warren selv har påpeget, så er der i den grad behov for empirisk og metodologisk at sætte fokus på "the material world" inden for den æstetiske referenceramme (Warren 2008, 561). I relation til det perspektiv som fremføres her, betyder det ikke at den individuelle og kollektive meningsskabelse er irrelevant. Det betyder blot at den er utilstrækkelig. Et objekt (eller et subjekt) er andet og mere end den mening det tilskrives af informanterne. Følger man ANT, så er én af de basale metodiske pointer at objekter og humane aktører skal studeres på lige fod; at man må følge et symmetrisk princip i sin analyse af det sociale (Latour 2005; Law 2007). Det betyder at objekterne skal tages alvorligt som objekter i den forstand at man som forsker forpligter sig på at beskrive objekternes agens. Det indebærer bl.a. en interesse for den omverden, herunder dets humane brugere, objektet aktivt er med til at skabe.

\section{'En god cykel med støtteben' - en analyse}

Overskriften er samtidigt tekstloggen til det auto-fotografi der danner afsæt for analysen. Billedet af støttebenet er udvalgt fordi det på særlig eksemplarisk vis kan illustrere det materielles betydning i relation til det man normalt betegner som 'det psyko-sociale arbejdsmiljø'. Ved at udfolde billedets kontekst/forbindelser bliver det synligt, hvordan støttebenet ikke blot er med til at stabilisere cyklen, men også den særlige konfiguration af trivsel og produktivitet som præger postarbejdet. Billedet af netop dette støtteben viser sig desuden at indeholde en historie om destabilisering; om hvordan teknologien, markedet, arbejdsopgaven og postarbejderen selv er under forandring og dermed udfordrer og destabiliserer den hidtidige relation mellem trivsel og produktivitet. Ved at følge cyklen og støttebenet forskellige steder hen i organisationen tegner analysen således konturerne af et langt større billede af hvad der konstituerer postarbejdernes arbejdsmiljø. Analysen har jeg inddelt i tre så læseren kan se hvad der sker med analysen efterhånden som flere mediationer, flere ressourcer føjes til. Jeg starter ved at skrive mig ind på det objekt billedet fokuserer på: cyklen m. støtteben. Denne del af analysen er dels inspireret af Latour's analyse af en dørlukker (Latour 1997), dels af det forhåndskendskab jeg havde til cykler, støtteben og postudbringning ${ }^{2}$. 


\section{Del I}

Fotografiet er et nærbillede der viser et lille udsnit af et objekt som man umiddelbart genkender som en cykel. En gul cykel parkeret på noget der kunne ligne et betongulv. Et rustent, men dog solidt udseende sort støtteben fungerer som støtte. Man behøver ikke at se resten for at vide at det er en cykel. Pedalerne, dele af et hjul, en kæde og en kædeskærm samt de gule stænger som holder det hele sammen gør, at man ikke er i tvivl. Man ved naturligvis ikke om cyklen er funktionel. Om den for eksempel mangler et styr eller et sæde. Men det er heller ikke vigtigt. Måden billedet er taget på, fortæller at det er noget andet man som beskuer skal lægge mærke til. Ud af de mange detaljer som fortæller at dette er en cykel, er det det lille sorte støtteben, placeret i billedets gyldne snit der træder frem. Med den korte tekst i tillæg bliver man kun des mere sikker i sin sag: "En god cykel med støtteben", tilføjer den. Billedets komposition og teksten henleder altså beskuerens opmærksomhed på denne lille metaltingest som normalvis hverken høster anerkendelse eller opmærksomhed, og slet ikke i arbejdsmiljøforskning. Denne opmærksomhed til trods gør det ikke mere klart hvordan det lille bevægelige metal objekt kan udgøre svaret på denne forskers spørgsmål: 'Hvad er en god arbejdsdag?'. I udgangspunktet er støttebenet ikke afgørende for at cyklen virker, som for eksempel hjulene, pedalerne eller kæden. Uden dem ville der slet ikke være nogen cykel, og heller ikke noget transportmiddel som åbenlyst er relevant når det gælder post distribution. På den anden side så er støttebenet meget nyttigt. Inspireret af Latours tankeeksperiment da han støder på en defekt dørlukker i La Halle aux Cuirs, så vil en cykel uden støtteben helt givet kræve langt flere anstrengelser. Det ville kræve en krop, en væg, et træ eller et andet stabilt objekt at støtte cyklen opad. I den sammenhæng ville kroppen have en åbenlys fordel sammenlignet med væggen og træet som måske nok er udskiftelige, men ikke mobile. Man kan ikke regne med at der er en væg eller et træ uanset hvor man kommer hen. I sidste instans kan jorden bruges, men det ville samtidigt betyde at der skulle bruges flere kræfter, og man ville risikere at forbipasserende kunne falde over cyklen. Kroppen lader til at være det mest oplagte alternativ. Den findes i umiddelbar nærhed af cyklen, og den er i stand til at forholde sig refleksivt til skiftende omgivelser, såsom forbipasserende, vind og vejr mv. En krop ville fungere som et tilpasningsdueligt støtteben. Men som med den menneskelige dørlukker i Latours tekst så er det at bruge et menneskeligt støtteben både dyrt og i sidste instans også mindre forudsigeligt. Menneskekroppen risikerer at blive syg, distraheret og kan heller ikke stå op i det uendelige. Menneskekroppen ville behøve pauser og dermed kræve anden støtte til cyklen. Lige så væsentligt at bemærke er at dette ikke er en hvilken som helst cykel, og ej heller en hvilken som helst menneskekrop. Det er en postcykel og en postarbejder. Karakteristisk for relationen mellem netop denne cykel og denne menneskekrop er at de ikke blot skal formå at stabilisere en cykel, men derimod distribuere post. Delegationen af kompetencer fra krop til støtteben, fra somatiske til "extra somatic resources" (Latour 1997, 246), er her helt afgørende. Støttebenet er dét objekt der gør det muligt for postarbejderen at transformere cyklen fra en bevægelig til en stående cykel, blot ved at gøre brug af den simple teknologi der ligger i kombinationen af et hængsel og et let spark. Det er samtidigt den teknologi som gør det muligt for postarbejderen at transformere sig: fra en krop med cykel til en krop uden cykel. Kroppens mobilitet øges. Den bliver i stand til at være et andet sted end cyklen. Ved hver postkasse kan cyklen transformeres ved hjælp af et spark, og postarbejderen kan 
bære posten hen til postkassen, vende tilbage til cyklen og atter sætte den i bevægelse. I den forstand er støttebenet afgørende i relation til arbejdsopgaven - at bringe post ud på ruten - og kan i det lys forklare hvordan et umiddelbart mondænt objekt kan få så stor betydning.

Det kan dog ikke forklare hvordan cyklen med støtteben er en del af en særlig god arbejdsdag. Det kalder på flere specifikationer: hvad betyder det f.eks. at noget er dårligt i denne konfiguration af cykler, støtteben, postarbejdere og post distribution? Hvordan ser det mon ud? Pointen er at det kan billedet og den korte tekst-log ikke fortælle. Det kræver yderligere distinktioner og dermed yderligere mediationer. Flere ressourcer skal involveres, netværket skal udvides. Det er disse ressourcer og dette udvidede netværk som er afsættet for analysens 2 . del.

\section{Del 2}

Gruppeinterviewet er en oplagt måde at udvide fotografiets netværk, og i løbet af interviewet bliver det klart at distinktionen mellem 'god' og 'dårlig' hænger sammen med arbejdsrutiner og tid. Men også 'større' spørgsmål som nye produkter og et liberaliseret postmarked viser sig at være en del af billedet. Ifølge postarbejderne er støttebenet på billedet en gammel version som nu er erstattet af en stor firkantet bøjle på gummihjul. Den stabiliserer cyklen ved at løfte hele cyklens forhjul op fra jorden. Det er en anden type teknologi som samtidigt kræver hele kroppens vægt at skubbe frem med det ene ben. Denne tungere, alternative løsning sikrer cyklens stabilitet. Ifølge postarbejderne i interviewet kan det gamle støtteben ikke længere bære den vægt som er påkrævet. Til trods for at Post Danmark generelt oplever en dramatisk tilbagegang i mængden af breve så er antallet og ikke mindst vægten af reklamer og øvrige tryk- sager steget markant. Det faktum gør det lille sorte støtteben til en risikabel affære. Den følgende historie og dialog illustrerer risikoen:

"P1: Jeg har til gengaeld prøvet at saette min cykel oppe på Kongensgade på de der fine hjul. Den stod fint da jeg gik derfra, så går jeg ned i nummer et eller andet og kommer tilbage igen (...)

P2: Så var den voek!

P1: (...) Så var den kørt ud på Kongensgade! Så lå brevene bare ud over hele Kongensgade $i$ begge retninger. $O g$ så kommer der en dame og siger 'Skete der noget, skete der noget?' 'Nej', siger jeg 'det gjorde der ikke'. Hun spurgte om hun kunne hjoelpe og jeg sagde 'Kan du ikke hjoelpe så brevene ikke flyver?' Fordi de lå jo sådan spredt $i$ én lang raekke, de ligger jo i nummerorden. Så jeg skulle have det hele skrabet sammen igen, så jeg havde det $i$ en stak. Hold kaeft, hvor var der mange breve! Og bilerne i begge sider, de holdt bare. Så lå al posten ud over det hele. Så det var bare sjovt!"

Det interessante ved historien er at den illustrerer vigtigheden af cyklens stabilitet og konsekvenserne når det ikke er tilfældet. Det er samtidigt en kommentar som faktisk taler imod den nye version. 'Situationen' indtraf netop til trods for 'de der fine hjul' på den store metalbøjle. Der er ingen tvivl om at den pågældende postarbejder foretrækker det lille sorte støtteben. Men hvorfor egentlig? Grundlæggende er det fordi det er meget nemmere at bruge, forklarer hun. Hængslet kan aktiveres mens man kører, hvilket giver mulighed for at opretholde en vis fart. Som en anden informant supplerer, så giver det lille støtteben mulighed for at man kan springe af og på fra begge sider af cyklen hvilket ikke er muligt med bøjlen der kun kan bruges fra cyklens venstre side. Med andre ord så giver det lille 
sorte støtteben mulighed for at postarbejderens krop kan nærme sig postkasserne på en langt mere fleksibel måde, og samtidigt udføre arbejdet hurtigere. Fleksibiliteten og hurtigheden lader altså til at være forklaringen på hvordan støttebenet er koblet til 'En god arbejdsdag'. Den historie viser sig samtidigt at resonere med flere af de øvrige billeder: billedet af den trimmede hæk, den glade hund og af postkassen. I samtlige tilfælde handler det om tilgængelighed og 'arbejds-flow': Den trimmede hæk gør det muligt at bakke den gule postbil hele vejen hen til postkassen, og således skåne postarbejderen for ekstra skridt og byrder; billedet af den glade hund som sidder tålmodigt og venter på sin hundekiks, står i modsætning til arrige og aggressive hunde som forhindrer postarbejderne i at udføre deres arbejde, eller sågar sender dem på skadestuen med bidmærker; og endelig billedet af postkassen som forbindes med en god arbejdsdag når den er tømt, og således uden forhindringer kan tage imod dagens post. På samme måde som med støttebenet er en god arbejdsdag for postarbejderne knyttet til situationer hvor arbejdet bare glider: Når arbejdet kan udføres hurtigt og med mindst mulig modstand. Man kan sige at den gode arbejdsdag er når trivsel og produktivitet smelter sammen i arbejdets rutiner.

\section{Del 3}

Som antydet ovenfor så relateres billedet af støttebenet dog til et opbrud i denne umiddelbare harmoni. Støttebenet er blevet erstattet af en ny version som udfordrer postarbejdernes sædvanlige kroppe og rutiner, og dermed også den særlige balance de har etableret mellem trivsel og produktivitet. Det gamle støtteben kan ikke længere sikre cyklen den nødvendige stabilitet. Støttebenet, men også hele postcyklen, er blevet underkastet en gennemgribende teknologisk udvikling som kan imødekomme de krav som tungere post og et liberaliseret postmarked aktualiserer. Fotografiet af cyklen med det sorte støtteben viser sig at hænge sammen med ikke blot nye produkttyper, men også udviklingen af en ny elcykel; skabelsen af fremtidige markeder og ikke mindst at tegne konturerne af en ny type postarbejder. I det jeg følger objektet, cyklen med støtteben, må jeg således forlade distributionscentret og postarbejderne og opsøge afdelingen for Distributions Udvikling i Post Danmarks hovedkvarter i København. Her sidder ingeniøren med ansvaret for at udvikle den ny el-cykel. Gennem interview med denne ingeniør, samt i læsningen af diverse test-rapporter bliver fotografiet af cykel og støtteben knyttet sammen med både de tekniske og markedsstrategiske overvejelser som i bogstaveligste forstand er bygget ind i den ny el-cykel. Jeg hører om batteri-teknologier, metaltyper og ikke mindst de grønne plastikbokse som er blevet udviklet som erstatning for de sorte kanvas tasker der tidligere hang på cyklerne. Boksene er særligt interessante, idet de ikke blot bekræfter det faktum at Post Danmarks produkter har ændret sig fra breve til tungere og langt mere standardiserede produkter, men samtidigt peger mod nye horisonter. Som udvikleren uddyber:

"Da vi startede det her projekt her, der havde vi jo sådan set sagt, at det skulle bare erstatte de cykler der var nu. Ikke noget videre. Men så som vi arbejdede videre med det, så fandt vi ud af, at vi var nødt til at kigge fremad. For ligesom at sige: hvad kan vi bruge det her materiel til. Så vi ikke kun udvikler det til: hvad skal det kunne nu. Det skal også kunne holde om 5 år, når vi har nogle andre produkter, eller noget andet at omdele, hvad ved jeg. Så hvordan fremtidssikrer vi det?"

Udover at elcyklen med bøjlestøttebenet er udviklet til at transportere og stabilisere 
langt flere kilo end den gamle model, så er den så at sige designet til at kunne bære vægten af et fremtidigt om end udefineret marked. Udviklingen af de grønne plastikbokse er et højst pragmatisk svar på netop det faktum. Forskellen mellem kanvastaskerne og de nye bokse er at sidstnævnte er udviklet efter standard pallemål. Dvs. at de i princippet kan transportere hvad som helst. Når Post Danmark satser på pallemål, taler de et standardiseret sprog som forstås på tværs af brancher. Det repræsenterer af den grund en fleksibilitet og en potentialitet $\mathrm{i}$ form af evnen til at kunne distribuere et utal af produkter: mad, dagligvarer, tøj eller noget helt fjerde. Som udvikleren ræsonnerer, så har det dog potentielt store konsekvenser for postarbejderne. Problemet er imidlertid at organisationen ikke forholder sig til at udviklingen af teknologier som cykler og støtteben har meget håndfaste effekter; ikke blot for den fremtidige forretningsstrategi, men også for postarbejdernes identitet, arbejde og arbejdsmiljø. Når udviklingsafdelingen designer cykler, så rammesættes det som et teknisk spørgsmål med det formål at skabe en drift-stabil teknologi som er i stand til at favne forestillinger om fremtidige markeder. At cyklen og dens specifikke funktionalitet samtidigt er definerende for postarbejderens krop, rutiner, produktivitet og trivsel, er der imidlertid ikke mange i organisationen der er opmærksomme på.

\section{Konklusion}

Konklusionen er delt i to dele. En empirisk del som koncentrerer sig om at konkludere på analysens bidrag til arbejdsmiljøfeltet; og en metodisk-analytisk del som forholder sig til foto-metodens potentialer som forskningsmetode. Opdelingen er alene foretaget af formidlingsmæssige grunde. Analysens evne til at gøre en forskel i arbejdsmiljøfel- tet er naturligvis uadskillelig fra vurderingen af metodens potentiale.

\section{På sporet af det socio-materielle arbejdsmiljø}

Analysen demonstrerer hvordan postarbejdernes trivsel ikke blot konstitueres af psyko-sociale faktorer, men i høj grad er forbundet med det konkrete arbejde og dets materialitet. Populært sagt så er medarbejdertrivsel også i støttebenet. Ved at forfølge 'den gode cykel med støtteben' og etablere forbindelser mellem auto-fotografiet, fotografen og teamet og videre til udvikleren, materialerne og markedet, understreger artiklen at et socio-materielt perspektiv på arbejdsmiljøet betyder en udvidelse, men også en forskydning af samme. Som påpeget af Abildgaard et al. (2012) så kan trivsel i et socio-materielt perspektiv netop ikke begrænses til psykologiske faktorer som det for eksempel kommer til udtryk i teorier om stress og coping (Lazarus \& Folkman 1984), eller i teorier om mening i arbejdet (Olsén 2008; Kamp 2011). Det er ikke tilstrækkeligt at forstå det som noget der afgøres i det sociale, mellem kollegaer, medarbejdere og ledere; sådan som det blandt andet tematiseres og teoretiseres i teorier om social kapital, tillid og retfærdighed (Thoft et al. 2008). Samtidigt indebærer den socio-materielle tilgang at det ikke er muligt på forhånd at definere de faktorer/arbejdsmiljø-aktører der har betydning. Inspireret af ANTs performative pointe er arbejdsmiljøet ikke noget som afdækkes og kortlægges, men derimod noget som gøres i analysen, og som dermed bliver langt mere kontekstspecifik og lokal i sin karakter. Et socio-materielt perspektiv på arbejdsmiljøet betyder at man indskærper blikket for de non-humane aktører i form af teknologier og artefakter, og at der i denne forskydning fra det psyko-sociale til det socio-materielle potentielt byder sig flere handlemulighe- 
der. Set i forhold til Post Danmark er konsekvensen at trivselsindsatser lige så vel kan fokuseres i materieludviklingen som i de sædvanlige indsatser rettet mod de humane ressourcer: team- og ledelsesudvikling, stresscoping-strategier med mere. Det betyder dog ikke at man skal se bort fra feltets humane aktører. Nye humane aktører kan derimod dukke op som relevante for arbejdsmiljøet, som for eksempel udvikleren der ikke normalvis forbindes eller forbinder sig selv med en arbejdsmiljødagsorden.

\section{Auto-fotografi som forskningsmetode}

Ved at gribe tilbage til og udfordre foto-metodens primært fænomenlogisk-æstetiske klangbund i forskningslitteraturen tydeliggør artiklen fotometodens potentiale ud fra en performativ forskerposition. En position som ikke baserer sig på at repræsentere feltets æstetiske kategorier så loyalt som muligt, men derimod tilbyder feltet nye måder at blive synlig på. I den forstand er den performative position politisk og handler her om at bidrage til en alternativ forståelse af trivsel, at forskyde fokus fra individet og det psyko-sociale til det organisatoriske og socio-materielle. Denne ambition har specifikke metodisk-analytiske implikationer for arbejdet med foto-metoden. Artiklen argumenterer for at karakteren af de empiriske og analytiske ressourcer som involveres i analysen har stor betydning for hvilket billede af trivsel og arbejdsmiljø auto-fotografierne kan være med til at synliggøre. Inspireret af ANT udfolder analysen stykke for stykke de forskellige elementer som auto-fotografiet er forbundet med og (gen)skaber et patchwork lignende billede af postarbejdernes socio-materielle arbejdsmiljø. For det første dvæler analysen ved objekterne i fotografiet, cyklen og støttebenet i et forsøg på at tage deres tilstedeværelse og agens alvorligt i forhold til postarbejdernes arbejde og trivsel. Objekter som generelt har en tendens til blive 'set igennem' når fotometoden for eksempel kombineres med interviews. For det andet udfordrer analysen tendensen til at lade fotografens subjektive meningsskabelse være den primære kilde til at forstå fotografiet. Vægten lægges i stedet på den kollektive meningsskabelse og fotografiets forbindelser til organisationen. For det tredje inddrages aktører og begivenheder, som for eksempel materieludvikleren, postmarkedet og standardiserede pallemål. Aktører som umiddelbart befinder sig 'langt væk' fra postarbejdernes hverdag og heller ikke optræder i deres fortællinger, men som ikke desto mindre viser sig at være en væsentlig del af billedet. På den måde demonstrerer analysen hvordan det at 'se' et autofotografi indebærer et omfattende analytisk arbejde med at beskrive det større netværk af humane og non-humane aktører der fungerer som medkonstituerende for autofotografiet, uanset at de ikke umiddelbart er synlige i billedet.

\section{Noter}

1 Auto-fotografierne blev taget i perioden 200910. Formålet var at foretage en eksplorativ undersøgelse af forbindelsen mellem trivsel og produktivitet blandt postarbejderne. To teams af postarbejdere fik udleveret et digitalt kamera og opgaven at tage billeder af: 'En god arbejdsdag'. Desuden skulle de tilføje en kort tekst der forklarede hvordan billedet hang sammen med temaet (Mogensen 2012).

2 Analysen er skrevet inden der kom et lovmæssigt krav om at alle postkasser skulle placeres ud til vejen/skel, hvilket alt andet lige har givet postarbejderne et mindre behov for et støtteben. 


\section{REFERENCER}

Abildgaard, S.J. et al. (2012): Bidrag til et symmetrisk og sociomaterielt arbejdsmiljøperspektiv, i Tidsskrift for Arbejdsliv 14, 3, 57-75.

Barthes, R. (1983): Det lyse kammer, København, Politisk Revy.

Bramming, P., B. G. Hansen \& K. G. Olesen (2009): SnapLog - en performativ forskningsteknologi, eller hvad grævlingelorten fortæller om lærertrivsel, i Tidsskrift for Arbejdsliv, 11, 4, 24-38.

Bramming, P. et al. (2012): (Im)perfect pictures: snaplogs in performativity research, i Qualitative Research in Organizations and Management: An International Journal, 7, 1, 54-71.

Chalfen, R. (2002): Snapshots 'r' us: the evidentiary problematic of home media, i Visual Studies, 17, 2, 141-149.

Gagliardi, P. (2006): Exploring the Aesthetic Side of Organizational Life, Chapter 25, i Clegg, S. et al. (red): The Sage Handbook of Organization Studies, Thousand Oaks, CA, Sage Publications Ltd.

Grimshaw, A. \& A. Ravetz (red.) (2005): Visualizing Anthropology, Bristol, UK \& Portland, OR, Intellect Ltd.

Haraway, D. J. (1991): Feminism and the privilege of partial perspective, i D. J. Haraway: Simians, Cyborgs and Women. The Reinvention of Nature, New York \& Oxford, Routledge.

Harper, D. (2002): Talking About Pictures. A Case for Photo Elicitation, i Visual Studies, $17,1,13-26$.

Hurdley, R. (2007): Focal Points: Framing Material Culture and Visual Data, i Qualitative Research, 7, 3, 355-374.

Johnsen, S., J. May \& P. Cloke (2008): Imag(in) ing 'homeless places': using auto-photography to (re)examine the geographies of homelessness, i Area, 40, 2, 194-207.

Kamp, A. (2011): Mening i arbejdet - for lidt, for meget, til forhandling?, i Tidsskrift for Arbejdsliv, 13, 2, 8-27.

Krøjer, J. (2010): Lever følelser i arbejdslivet? Et poststrukturalistisk alternativ, i Tidsskrift for Arbejdsliv, 12, 1, 9-21.

Latour, B (1997): Where Are the Missing
Masses. The sociology of a few mundane artifacts, i W. Bijker \& J. Law (red.): Shaping Technology/Building Society, Cambridge, MA, MIT Press.

Latour, B. (2004): How to Talk About the Body? The Normative Dimension of Science Studies, i Body and Society, 10, 2/3, 205-229.

Latour, B. (2005): Reassembling the Social. An Introduction to Actor-Network-Theory, New York, Oxford University Press.

Law, J., (2007): Actor Network Theory and Material Semiotics. Available at:

http://www.heterogeneities.net/publications/Law-ANTandMaterialSemiotics.pdf

Lazarus, R.S \& S. Folkman (1984): Stress, Appraisal and Coping, New York, Springer Publishing Company.

MacDougall, D. (2006): The Corporeal Image. Film, Ethnography, and the Senses, Princeton, NJ, Princeton University Press.

Mogensen, M. (2012): The Organization(s) of Well-being and productivity. (Re)assembling work in the Danish Post, PhD Series 38.2012, Frederiksberg, Copenhagen Business School.

Mogensen, M. (2011): What is the 'more' of photographic methods? Paper for $2^{\text {nd }}$ workshop on Imagining Business, Segovia Spain May 2011.

Thoft, E., P. Hasle \& T. S. Kristensen (2008): Virksomhedens sociale kapital, København, Arbejdsmiljørådet.

Olsén, P. (2008): "Hvis vi bare ku' få fred til at passe vores arbejde..." - om mening, forandring og psykisk arbejdsmiljø, i Tidsskrift for Arbejdsliv, 10, 4, 43-58.

Pedersen, M. (2008): Tune in, Break down, and Reboot - New Machines for Coping with the Stress of Commitment, i Culture and Organization, 14, 2, 171-185.

Pink, S. (2009): Doing Sensory Ethnography, London, Sage Publications Ltd.

Pink, S. (2001): Doing Ethnography: Images, Media and Representation in Research, London, Sage Publications Ltd.

Pink, S., L. Kürti \& I. Afonso (red.) (2004): 
Working Images. Visual Research and Representation in Ethnography, New York \& Oxford, Routledge.

Strati, A. (2000): The Aesthetic Approach in Organization Studies, i S. Linstead \& H. Höpfl: Aesthetics of Organization, London/ Thousand Oaks /New Delhi, Sage Publications Ltd.

Strati,A. (2008): Aesthetics in the study of Organizational life, i D. Barry \& H. Hansen: The Sage Handbook of New Approaches in Management and Organization, London/ Thousand Oaks/New Delhi/Singapore, Sage Publications Ltd.

Strati, A. (2009): Do you do beautiful things? Aesthetics and Art in Qualitative Methods of Organization Studies, i D. Buchanan \& A. Bryman: The Sage Handbook of Organizational Research Methods. London/Thousand Oaks/ New Delhi/Singapore, Sage Publications Ltd. Staunæs, D. (2000): Engangskameraer og børneblikke, i P. Schulz-Jørgensen \& J. Kampmann (red.): Børneperspektiver og børn som informanter, København, Børnerådet.

Schwartz, D. (1989): Visual Ethnography: Using Photography in Qualitative Research, i Qualitative Sociology, 12, 2, 119-154.

Shortt, H. \& S. Warren (2012): Fringe benefits: valuing the visual in narratives of hairdressers' identities at work, i Visual Studies, 27, 1, 18-34.

Sørensen et al. (2007): Indflydelse i vidensarbejdet - kan man få for meget af det gode?, i Tidsskrift for Arbejdsliv, 9, 2, 38-54.

Warren, S. (2002): 'Show me how it feels to work here': using photography to research organisational aesthetics', i Ephemera - Critical Dialogues on Organisation, 2, 224-245.

Warren, S. (2005): Photography and voice in critical qualitative management research, i Accounting, Auditing \& Accountability Journal, $18,6,861-882$.

Warren, S. (2008): Empirical challenges in Organizational Aesthetics Research: Towards a Sensual Methodology, i Organization Studies, $29,4,559-580$.

Mette Mogensen, cand. mag, ph.d., adjunkt, Institut for Organisation, CBS e-mail:mmo.ioa@cbs.dk 